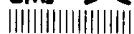

\title{
ニューラルネ梳で統合するフアジ逆推論を 用いた自動車デザイン支援システム
}

\author{
張 育銘*1 森 典彦*2
}

デザイナーの負担を軽減し，さらにデザイナーの発想を刺激するため，いろいろな造形支援シス テムが研究されている. システムはデザイナ一の思考過程をモデル化し，そのモデルを用いて推論 する。しかし往々にしてこれらのシステムはつぎの二つの問題を含むことが多い。すなわち，1)変 数に計測尺度と感覚尺度が混在する，2）推論過程がデザイナ一の思考のような柔軟性に欠ける.

これらの問題に対して, 筆者らは本研究において, 1) 造形対象の形態要素に関する計測尺度変数 をファジィ集合によって感覚尺度化，2)推論過程にファジィ逆推論を利用して造形解に幅をもたせ た柔軟なモデルを提案する。ささらに, デザイン問題の性質としてのファジィ関係式のあいまい性を 包括するために, ニューラルネットワークモデルによる推論をシステムに導入する。本研究では自 動車の外観イメージからスタイルの造形解を求める過程を事例に選んで造形支援システムを構築 し，実際のデータを使ってモデルの有効性を確かめた。

キーワード：ファジイ逆推論, ニューラルネットワーク, 感覚尺度, 造形, 自動車, デザイン

\section{1. 研究の目的と概要}

\section{1 研究の背景と目的}

近年，デザイナーの作業負担を軽減し，効率を 向上させるために，コンセプト設定からスタイル の造形に至るまでのデザイン作業を支援するシス テムが必要になり，これをテーマにした研究も増 えている。これらの研究には，だいない 2 種類が ある。

その 1 は，ある形態要素の組み合わせのとき， どのようなイメージになるかを推論する。従って， デザインのための支擐モデルというより，デザイ ン後の評価予測モデルというべきものである.

その 2 は, イメージの組み合わせとしてのある コンセプトに対して形態要素の最適な組み合わせ を推論する，いわばデザイン支援モデルである。 しかし，これらのモデルは一般につぎの問題を含

\footnotetext{
† A Design Support System For Cars Using Fuzzy Inverse Reasoning Integrated by Neural-Network

Yu-Ming CHANG, Norihiko MORI

*1 千葉大学大学院

Graduate School of Chiba University

*2 千葉大学

Chiba University
}

む.

1)これらのモデルにおける[形態要素対イメー ジ用語]は[計測尺度对感覚尺度]で表される变数 を用いるのがふつうであるが，異種の尺度の混在 がモデルの妥当性に問題をもたらす。

2) あるコンセプトがイメージ用語の組み合わせ として提示されるときに，形態からのイメージの 評価をそのまま逆にしてイメージから形態を推論 しているため, 特化された形態要素のみが解とな り，デザイナーの行う思考のような柔軟性に欠け る.

本研究はこれらの問題に对処することを目的と する。すなわち形態要素を表す変数として，形そ のものの計測值でなく, 人の認知の程度を示す感 覚的尺度を用いることで, [形態要素対イメージ用 語］を[感覚尺度对感覚尺度］とし, 異種の尺度の混 在を避ける。次にイメージ用語から形態要素の推 論に, ファジィ逆推論を用いる。形態からイメー ジを評価するのを順推論とみなすことに対する逆 推論であり，ファジィ逆推論により幅のある柔軟 な解を与え，デザイナーの思考に近いモデルとす る. 
また自動車の外観をサンプルとして実際のデー 夕を調べたところ, 形態要素対イメージ用語のフ アジィ関係はサンプル間で不定性を示し，かなり あいまいであった。これはデザイン問題がもつ一 般的な性質と思われる。そこでサンプルごとにフ アジィ逆推論するとともに，全体をまとめる手段 としてニューラルネットワークモデルで推論を行 うようなモデルを提案した。

\section{2. 研究対象}

本研究は事例として一般乗用車の外観シルエッ 卜を対象とした。サンプル車は表 1.1 に示す 40 市 眅車を選んだ。

形態要素については，文献1）を参考にしながら 以下の 11 項を本研究では代表として選んだ(四 1.1).

(1)全高／全長比 $(\mathrm{D} / \mathrm{A})$.

(2)フロント長 $/$ 全長比 $(\mathrm{B} / \mathrm{A})$.

(3)リヤ長 $/$ 全長比 $(\mathrm{C} / \mathrm{A})$.

(4) $\mathrm{A}$ ピラーの傾斜度 $(=\mathrm{H})$.

(5) $\mathrm{C}$ ピラーの傾斜度 $(=\mathrm{I})$.

(6)バンパーの突出度 $(=\mathrm{E} / \mathrm{B})$.

(7)バンパーの厚さ $(=\mathrm{F} / \mathrm{B})$.

(8)丸み。

(9)ウエストライン高／全高 $(G / D)$.

(10)ウストラインの傾斜度 $(=\mathrm{J})$.

(11)フロントの傾斜度 $(=\mathrm{K})$ 。

表1.1 サンプル車一覧表
ここで(8)「丸み」だけは計測できないので感覚 的に判定することになるが, 以後の感覚尺度化の 過程を他の項目と揃えて行うため, 一旦疑似計測 值として 1 から 9 までの整数值を写真判定によっ てサンプル車に与えな。

コンセプトに用いるイメージ用語については， 互いに違う意味をもつ7 個のイメージ用語を本研 究では代表として選んだ。

(1)先進的な感じ.

(2)シャープな.

(3)おしゃれな。

(4)洗練された感じ.

(5)知性を感じさせる.

(6)オーソドックスな魅力.

(7)大人の落ちついた魅力.

\section{3. 研究の流れ}

本研究の過程を図 1.2 に示す。全体に 3 大段階 に分ける：準備段階，構成段階と検証段階。それ ぞれの概要は以下の通りである。

1)準備段階の目的は, 研究に用いるデー夕の作成 である．形態要素の抽出とイメージ用語の選択， さらに, 形態要素をメンバーシップ関数を使い感 覚尺度に変換する。

2)構成段階の目的は，推論モデルの構成である。 前段階で得られたデータから，サンプル車ごとに ファジィ関係式のファジィ同定を行うとともに,

\begin{tabular}{|c|c|}
\hline 1. ヘルソナ & 21 ヘヘンッ $560 \mathrm{SEL}$ \\
\hline 2. オペルベクトラ（蚶色） & 22. BMW735i \\
\hline 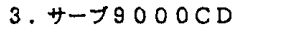 & 2 3. セルシオ \\
\hline 4.レジント & 24.フェアレディZ \\
\hline 5.ママキシマ & 25. RX -7 \\
\hline 6.オベルオメカ & 26.セリカ \\
\hline 7. アゥティ 80 & 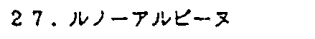 \\
\hline 8.アコード & $28 . M R-2$ \\
\hline 9. プメーラ & 29.ポルシェ911 \\
\hline 0. カムり & 30. フショー \\
\hline 1. ブジョ-405.SR I & 31.スカイライン \\
\hline 2. コンチェルト & $32 . \nabla ー ク \mathbb{I}$ \\
\hline 3.スプリンター & 33. オペルベクトラ（全色） \\
\hline 4. サニー & 34. セフィーロ \\
\hline 5. シとック & 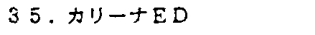 \\
\hline 6. ジェミニ & 36. BMW $535 \mathrm{i}$ \\
\hline 7. カロー5 & 37.ファミリア \\
\hline 8. ティムラーXJ 40 & 38. ローレル \\
\hline 9. リンカーンコンチネンラル & 38. キ+ラン \\
\hline 0.インフィニティQ45 & 40.パサートGT \\
\hline
\end{tabular}

1. ベルソナ

7. アゥティ 80

8.アコート

11.ブジョー

14. $\forall=$

15 ・シヒック

17.カ口ロ

19. リンカーンコンチネンタル
A. 全要
B.フロント長
C. リヤ長
D. 全离
E.パンバーの突出
F.パンバーの厚
G.ウエストライン高
H.Aビラーの倾斜度
I. Cビラーの傾斜度
J.ウエストラインの佰斜度
K.フロントの傎斜度

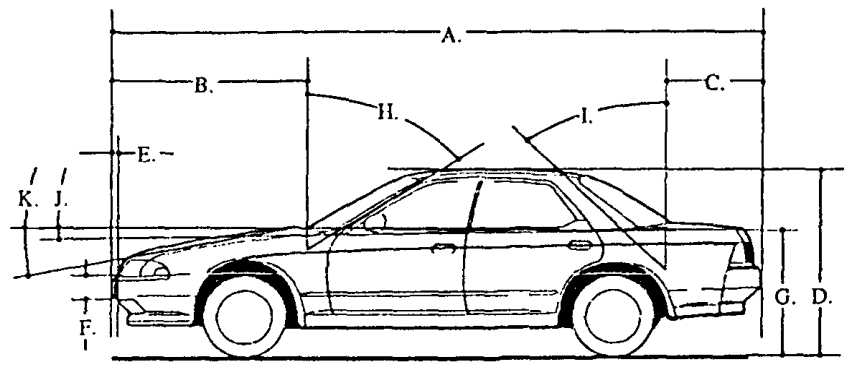

図1.1乗用車における各形態要素 
同定された関係式によりサンプル車ごとのファジ イ逆推論で逆解を求める. 最後に, パーセプトロ ン型のニューラルネットワークモデルを導入し， このサンプル 40 車の逆解についての学習をする. 3)検証段階の目的は, モデルの有効性の検証であ る。デザインに適用するモデルの有効性を実例の 推論結果により検証する.

\section{2. 形態要素のファジィ変換}

\section{1. 变換の目的及び方法}

この節では, 計測尺度の形態要素をいかに感覚 尺度へ变換するかの考え方と方法を述べる。

[計測尺度対感覚尺度]とは, 例之ば[この車の高 さが 0.32 (計測值)なので, ややシャープな感じ (感覚值)がする]であり, [感覚尺度対感覚尺度]と は[この車の高さがやや低いので(感覚値), ややシ ヤープな感じ(感覚值)がする]という考え方であ る。後者の方が人間の認知の害態を表すと思われ る.形態要素に関するこの変換のためにメンバー シップ関数を導入する。

人間の感覚值は [大・中・小]の 3 種が最も一般 的で認識しやすいと思われる。従って, 各形態要 素をそれぞれ 3 個の感覚尺度に変換して，例えば， 車高については，[大 $\rightarrow$ 背の高い車，中 $\rightarrow$ ちちらと もいえない高さの車, 小 背の低い車]として, さ らに，中間的な值を形容詞の[やや]などとして， メンバーシップの形式で表現する方法を考察して 本モデルに取り込んだ。

形態要素は 11 個であるので感覚的形態要素す なわち形態に関するファジィ集合は 33 個である。

\section{2. メンバーシップ関数の考え方と決定}

形態に関するファジィ集合のメンバシップ関数 (以下 MF で表す)を決める。関数式については指 数関数を用いて，図 2.1 に示すような連続的釣り 鐘型を導入した。三角形や台形型のような不連続 点の不自然さを避けるためである．指数関数の数 式を式(2.1)に示す ${ }^{233}$.

$$
\mu_{\tilde{r}}(x)=e^{-a\left(|(x-r) / d|^{b}\right)}
$$

$\tilde{r}:$ 形態要素のファジィ集合

$x$ : 形態要素の計測値変数

$r: M F=1 の x$ 值

$b$ : 乗変数 $a$ : 倍数変数 $d:$ 変換係数

まず $r$ すなわち $M F=1 の x$ 值を決める，例え ば車高については感覚尺度化したファジィ集合の [どちらともいえない車]に対しては全サンプル車 の車高の平均值とするのが妥当であろう，同様に [背の高い車]と[背の低い車]に対してはそれぞれ

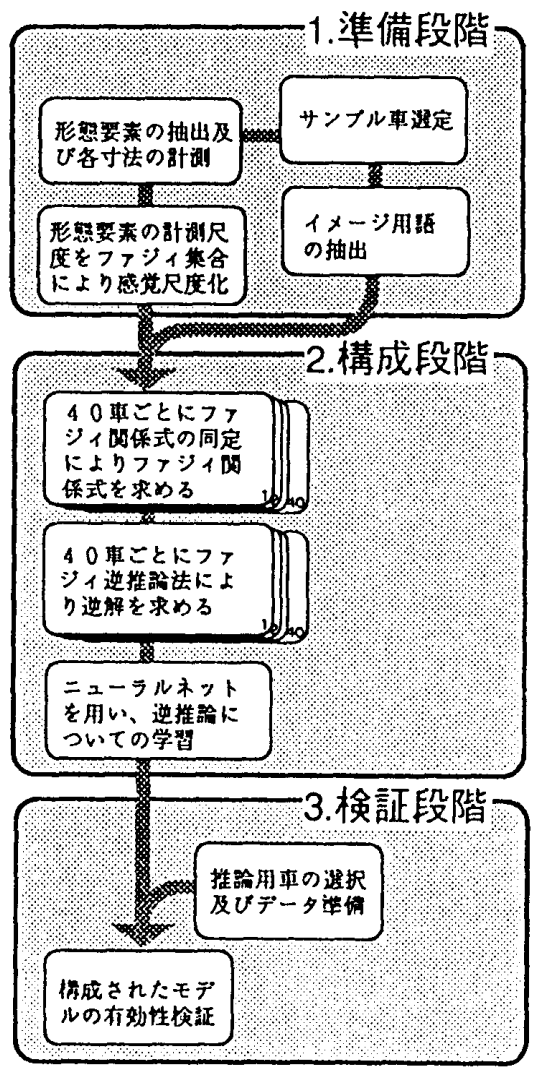

図1.2 研究の流れ

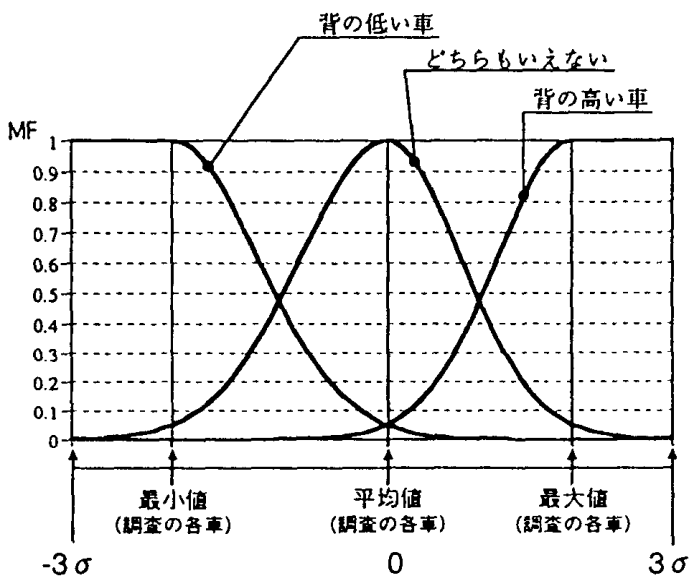

図2.1 MF の形 
全サンプル車の車高の最大值と最小值とする.

さらに $x$ のとり得る範囲については，本研究の 目的である推論の可能範囲を考えると，サンプル 車の範囲では不足であろう。そこで本研究で使用 した 40 サンプル車の各形態要素の $x$ の分布を調 べ，仮に正規分布で近似してみる，すると最小值 一平均值及び平均值一最大值の範囲は概ね $2 \sigma(\sigma$ は標準偏差)であり, 乗用車母集団の $95.4 \%$ が含 まれると考えられる。ここでは各形態要素とも上

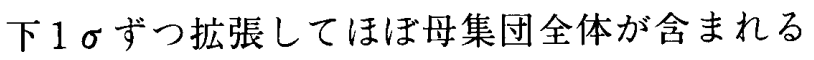
$(99.7 \%)$ よう, $x$ の範囲を拡大寸る.以上のことを 図 2.1 に模式的に示す.

つぎに $b$ (乗変数) と $a$ (倍数変数)を決める. 関 数の形がこれらによって具体的に定める.

考え方として, 本システムを使って形態要素を 推論したときの出力值はファジィ集合でなく, 計 測值と同様の確定值としたいので, 推論後になん らかの方法で非ファジィ化しなければならない. 非ファジィ化で得られる值が妥当かどうかは, 試 みに例えば車高についてのある計測值 $x$ を[背の 高い車], [どちらともいえない高さの車], [背の 低い車]の 3 個のファジィ集合へのメンバシップ で表した(感覚尺度化)とき，それがイメージの組 み合わせからのなんらかの推論結果である 3 個の ファジィ集合への適合度であるとして，それを非 ファジィ化(計測尺度化)したときに元の計測值 $x$ に一致するかどうかが一つの評価法である。それ は関数の形と非ファジィ化の方法に関わる.

ここでは推論結果は各ファジィ集合の適合度に よる頭切り法で求め, 非ファジィ化はそれらの和 に対する重心法で求めるものとし，そのときに上 記の意味で妥当であるような関数の形を $a, b$ の 操作によって求める．以上の考え方を図 2.2 に模 式的に示す.

非ファ:ジィかで求めた值と元の計測值との一致 度を $a$ と $b$ を変えて調べる. 図 2.3 はその一部で ある、横軸に非ファジィ化で求めた值, 縦軸に元 の計測値を示す.

いずれも完全には一致せず, 大・中・小の 3 個 所で非ファジィ化の値が膨らんだ傾向を示す。し

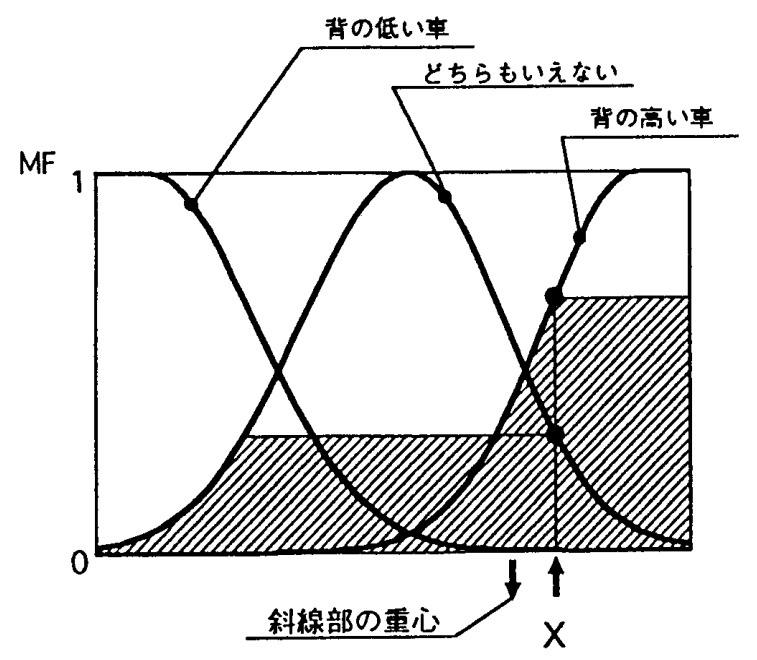

ある計測值メをファジィ集合のメンパシッブ で表し、それを推論結果の適合度とみなして 頭切り法/重心法で非ファジィ化した值が坏 近似するかを評価している。

図2.2 非ファジィ化の模式困 (関数の形を評価する)
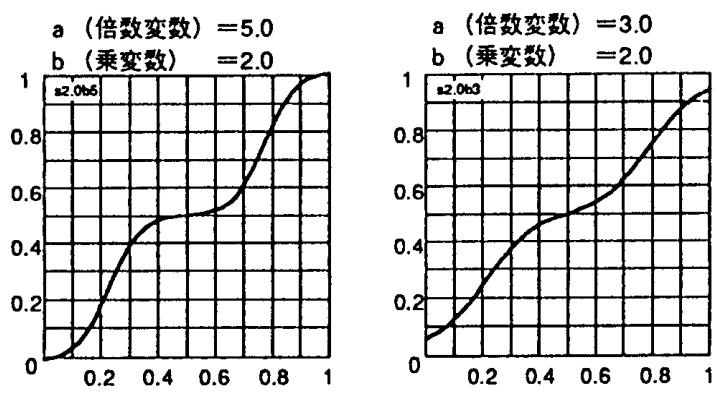

a (倍数变数) $=5.0$
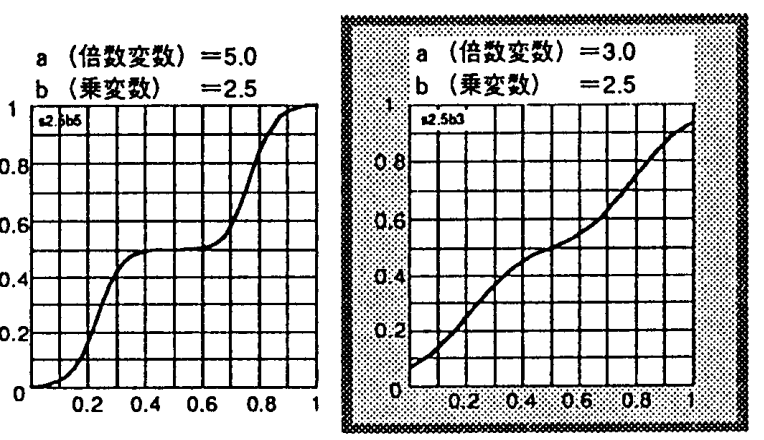

a (倍数变数) $=5.0$ b (乘夜数) $=3.0$
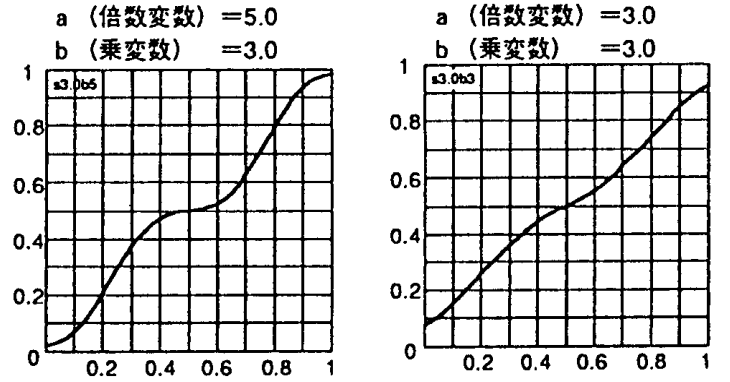

図2.3 非ファジィ化の值と元の計測値の比較 
かしこの傾向は，少しの程度ならば問題ないと思 われる。なぜなら筆者らの考えでは人の認知は恐 らく感覚量を認知するごとにややカテゴリカル （大・中・小）にバイアスがかかり，連続とカテゴ リカルの中間の形で認知すると思われるので，例 えば 0.25 近辺は[小寄り]と［中寄り］にずれて認 知するのが真相に近いと思われる。従って推論結 果としてこのような傾向を有する非ファジィ化の 值をもって元の計測值に代えて差し支えないであ ろう。

以上のほか, 関数の形が不自然になるような $a$, $b$ の值を避けるということも確かめながら(図 $2.4), a=3, b=2.5$ として式(2.2)を用いることに した. (図 2.3 では網掛け枠で囲って示してある)

$$
\mu_{\widetilde{r}}(x)=e^{-3\left(|(x-r) / d|^{2.5)}\right.}
$$

尚, 変換係数 $d$ は形態要素ごとに尺度が異なっ ているので，計測した実寸法 $x$ を基準化するため の係数であって， $x$ が平均值より大きい場合は $d=[$ 最大值一平均値 $]$ となり, 平均值より小さい 場合は $d=[$ 平均值一最小値 $]$ となる。

\section{3. 形態要素のファジィ変換の結果}

11 個の形態要素の值を写真から測り, その平均 値及び最小值，最大值を表 2.1 に示す。さらに， 式(2.2)を用いて，作成した 11 形態要素の変換 MF 形状図を図 2.5 に示す。
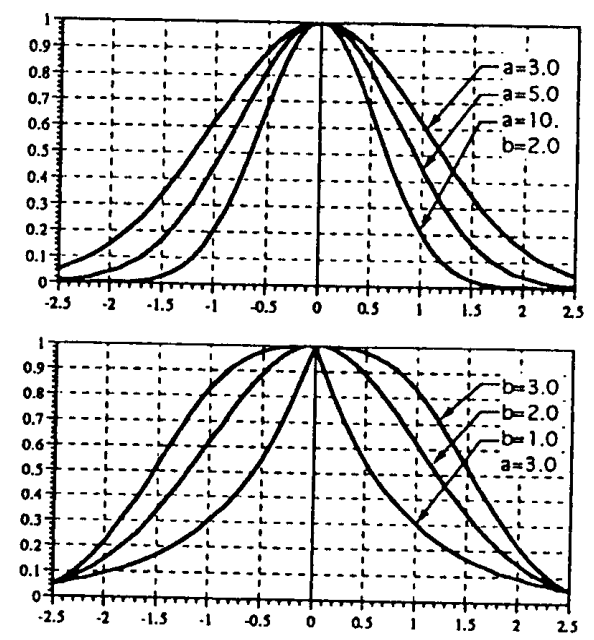

図2.4 b, a の変化と関数の形
表2.1 各形態要素の平均、最大、最小值

\begin{tabular}{|c|c|r|r|r|}
\hline 形隼要菜 & 単位 & 平均值 & 最大值 & 最小值 \\
\hline (1) & 比率 & 0.309 & 0.336 & 0.278 \\
\hline (2) & 比率 & 0.282 & 0.342 & 0.251 \\
\hline (3) & 比率 & 0.143 & 0.193 & 0.051 \\
\hline (4) & 角度 & 30.425 & 34.685 & 23.624 \\
\hline (5) & 角度 & 28.778 & 39.428 & 8.425 \\
\hline (6) & 比率 & 0.054 & 0.130 & 0.000 \\
\hline (7) & 比率 & 0.251 & 0.318 & 0.101 \\
\hline (8) & 比率 & 5.550 & 9.000 & 1.000 \\
\hline (9) & 比率 & 0.659 & 0.692 & 0.570 \\
\hline (10) & 角度 & 1.517 & 2.831 & 0.000 \\
\hline (11) & 角度 & 9.708 & 14.821 & 5.056 \\
\hline
\end{tabular}
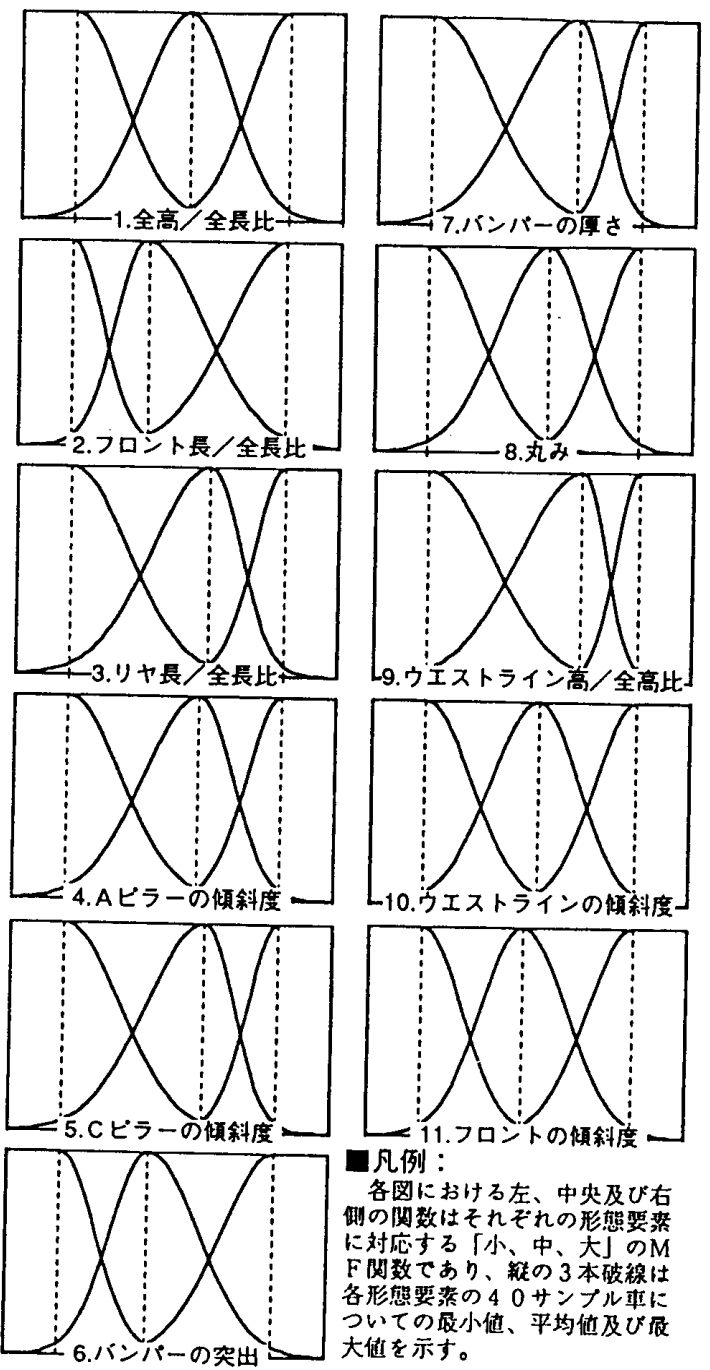

凡例 :

各图における左、中央及び右

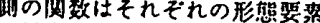
に対底する[小，中、大]のM

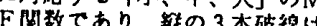

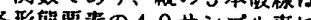

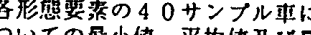
ついての展小优、平均优及び展 大优を示す。

図2.511形態要素の関数形状図 


\section{3. イメージ用語から形䈍要秦への逆推論}

\section{1.考方方}

デザイナーのデザイン過程は一種の逆推論過程 といえる，一般に人が物を見たとき，その形態要 素の組み合わせに対してイメージを感じる，逆に， デザイナーはあるイメージに対して形態要素の組 み合わせを求めなければならないので，デザイン ワーク中に常に逆推論を行っている．本支援シス テムはその逆推論に沿ったものでなければならな い. さらに，提示する解は，デザイナ一の発想が 一つの決定的な解を推論するのでなく，ある程度 の自由を持たせた柔軟な解を推論することをふま え，ここでも決定的な単独解よりも幅のある柔軟 な解を求められるシステムが適当と思われる，従 って，ファジィ逆推論法を用いる。

形態要素の組み合わせとしてのサンプル車から 得られるイメージに関するデー夕は，サンプル車 40 車の写真を被験者 80 人に見せ, 各イメージ用 語とも [全く感じない]から[非常に感じる]までの 7 段階でアンケート調査をして人について平均值 をとり，それを $[0,1]$ に比例変換した数值である. これを各イメージの感覚尺度上の確信度とした。 この章は，ファジィ関係式の同定問題とこのフ ァジィ関係式に基づく逆推論の問題について触れ る.

前章のファジィ集合化された形態要素とアンケ 一ト調査から得られたイメージ確信度を用いてフ アジィ関係式を同定する・

$$
\widetilde{A} \bigcirc \widetilde{R}=\widetilde{B}
$$

(3.1)式をファジィ関係方程式とする. $\widetilde{A} は$ 各形 態要素を 3 個のファジィ集合で表現したものを要

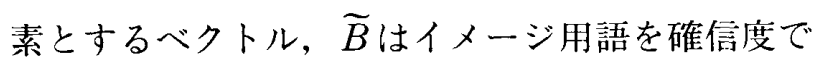
表現した数值を要素とするべクトルであり， $\widetilde{R} は$ ファジィ関係の行列である。

$$
\begin{aligned}
& \widetilde{A}=\left[a_{1}, a_{2}, \cdots \cdot a_{i}\right] \\
& \widetilde{B}=\left[b_{1}, b_{2}, \cdots \cdot b_{j}\right]
\end{aligned}
$$

$$
\widetilde{R}=\left[r_{i j}\right] \quad i=1, \ldots, 33, \quad j=1, \ldots, 7
$$

ここで, 全 40 サンプル車を 1 個のファジィ関係 式にするのは無理があることが分かった。サンプ ル車全体では現実に形態要素ベクトルもイメージ 用語ベクトルもパターンとしての種類が多彩であ り，従って両者間の関係も極めて複雑だからであ る。あえて 1 個の関係式にまとめると非常に幅広 い可能性を与えるのみで本研究の目的である支援 システムにならない.そこでまず 40 サンプル車の ファジィ関係式を別々に求める。

\section{2. ファジィ関係式の同定法}

$\widetilde{A}$ と $\widetilde{B}$ が既知で， $\widetilde{R}$ を求める問題は同定問題で

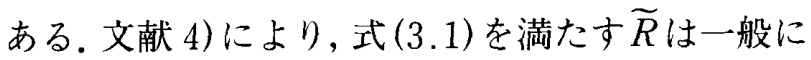
ただ一つではなく複数個存在する。ここではそれ らの解を代表する解，最大解と極小解を求める方 法を用いた。なお， $\widetilde{R}$ が存在するならば，極小解 $\subset \widetilde{R} \subset$ 最大解の条件を満なす。

同定のアルゴリズムは, 文献 4)の $\alpha$-合成 (最 大解)， $\sigma$ 一合成(極小解)を利用している.

$\alpha$ 一合成演算は次に示すような演算規則：

$$
a_{i} \alpha b_{j}=\left(\begin{array}{lll}
1 & \text { if } & a_{i} \leqq b_{j}(3.2) \\
b_{j} & \text { if } & a_{i}>b_{j}(3.3)
\end{array}\right.
$$

$\sigma$ 一合成演算は次に示すような演算規則：

$$
a_{i} \sigma b_{j}=\left\{\begin{array}{lll}
0 & \text { if } & a_{i}<b_{j}(3.4) \\
b_{j} & \text { if } & a_{i} \geqq b_{j}(3.5)
\end{array}\right.
$$

これらの $\alpha$-合成, $\sigma$ 一合成を利用して 40 サン プルについて $\widetilde{R}$ 求めた。 その一例を表 3.1 に示 す(部分).

この $\widetilde{R}$ を眺めると，以下の問題がある：1)後の 逆推論とそれを用いるデザイン作業の便宜を考慮 するとここでの $\widetilde{R} の$ 幅は大きすぎ，できれば一つ の関係式 $\widetilde{R}$ に絞りたい，2) $\widetilde{R} に は$ 形態要素のファ ジィ表現 $a$ の数值が反映されてないが, デザイン 上の実際として形態要素の組み合わせによりイメ ージが決まるので，できれば $a$ の数值も反映した い.

これらの問題に対して[双方向同定法]を提案す 
る，双方向同定法は，順同定と逆同定との 2 つを まとめたもので, 順同定とは上述 $a \alpha b$, 逆同定と は $b \alpha a$ である. 同定のアルゴリズムは以下に示 す。

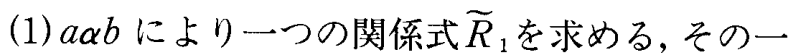
例を既に表 3.1 に示した。

(2) baaにより，もう一つの関係式 $\widetilde{R}_{2}$ を求める,
その一例を表 3.2 に示す.

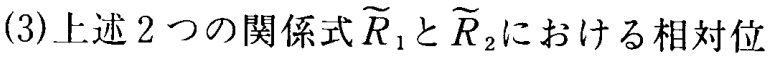
置の積集合をとって，一つの関係式 $\widetilde{R}$ を求め た。

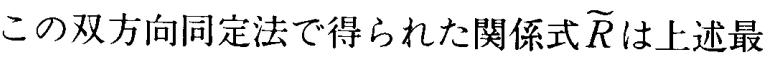
大解と極小解の間にあるという条件を満足し，式 (3.1) も満足していることを確認したので, 妥当性

表3.1 同定後の $\widetilde{R}_{1}$ (部分)

\begin{tabular}{|c|c|c|c|c|c|c|}
\hline & 用珸(1) 0.576 & 用鼓(2) 0.712 & 用語(3) 0.414 & 用酟 (6) 0.459 & 用謤(7) 0.630 \\
\hline 形 & 0.061 & {$[0.000,1.000]$} & {$[0.000,1.000]$} & {$[0.000,1.000]$} & {$[0.000,1.000]$} & {$[0.000,1.000]$} \\
\hline 冤 & 0.999 & {$[0.576]$} & {$[0.712]$} & {$[0.414]$} & {$[0.459]$} & {$[0.630]$} \\
\hline (1) & 0.039 & {$[0.000,1.000]$} & {$[0.000,1.000]$} & {$[0.000,1.000]$} & {$[0.000,1.000]$} & {$[0.000,1.000]$} \\
\hline 形 & 0.016 & {$[0.000,1.000]$} & {$[0.000,1.000]$} & {$[0.000,1.000]$} & {$[0.000,1.000]$} & {$[0.000,1.000]$} \\
\hline 密 & 0.996 & {$[0.576]$} & {$[0.712]$} & $[0.414]\}$ & {$[0.459]$} & {$[0.630]$} \\
\hline (2) & 0.084 & {$[0.000 .1 .000]$} & {$[0.000,1.000]$} & {$[0.000,1.000]$} & {$[0.000,1.000]$} & {$[0.000,1.000]$} \\
\hline 形 & 0.001 & {$[0.000,1.000]$} & {$[0.000,1.000]$} & $[0.000,1.000]\}$ & $\{0.000,1.000]$ & {$[0.000,1.000]$} \\
\hline 奀 & 0.320 & {$[0.000,1.000]$} & {$[0.000,1.000]$} & $[0.000,1.000]\}$ & $\{[0.000,1.000]$ & {$[0.000,1.000]$} \\
\hline (3) & 0.839 & {$[0.576]$} & {$[0.712]$} & $[0.414]\}$ & {$[0.459]$} & {$[0.630]$} \\
\hline 形 & 0.792 & {$[0.576]$} & {$[0.712]$} & $[0.414]\}$ & {$[0.459]$} & {$[0.630]$} \\
\hline 悪 & 0.374 & {$[0.000,1.000]$} & {$[0.000,1.000]$} & {$[0.000,1.000]$} & {$[0.000,1.000]$} & {$[0.000,1.000]$} \\
\hline (11) & 0.001 & {$[0.000,1.000] \mid$} & {$[0.000,1.000]$} & $\{[0.000,1.000]\}$ & $\{[0.000,1.000]$ & {$[0.000,1.000]$} \\
\hline
\end{tabular}

表3.2 同定後の $\widetilde{R}_{2}$ (部分)

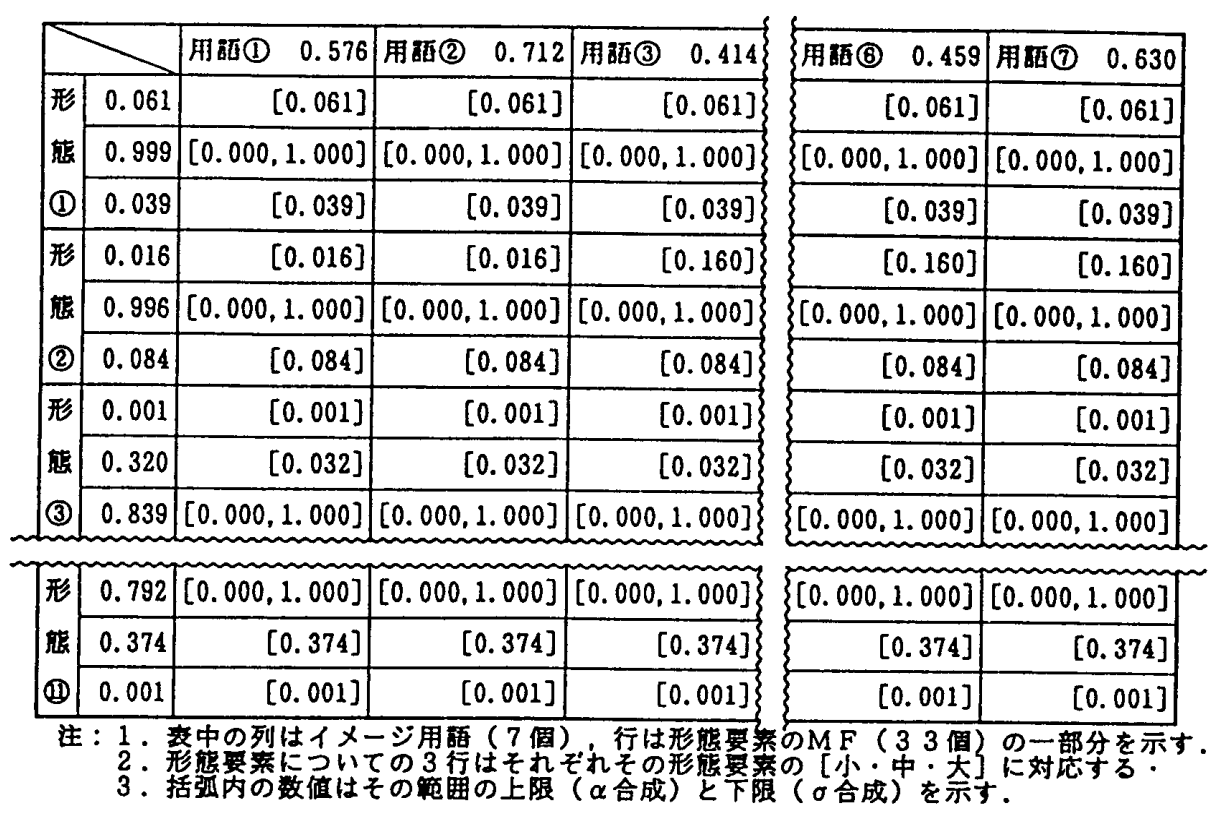


があると思われる。

従って，40 サンプル車をこの双方向同定法を利 用して求めた。 その一例を表 3.3 に示寸(部分).

\section{3. ファジィ関係式による逆推論法}

$\widetilde{R}$ と $\widetilde{B}$ が既知で, $\widetilde{A}$ を求める問題が逆問題(逆推 論)である。これにより，幅のある解が得られる。 計算は，塚本 ${ }^{556) 7} の \omega 一$ 合成 (上限值)， $\widetilde{\omega}$ 一合成 (下限值)を利用している.

尚，下述の演算における $r, a, b$ は 3.1 節と同 じ意味である。

๗一合成演算は次に示すような演算規則：

$$
r_{i j} \omega b_{j}=
$$

$$
\begin{cases}b_{j} & \text { if } r_{i j}>b_{j} \\ {\left[b_{j}, 1\right]} & \text { if } r_{i j}=b_{j} \\ \phi & \text { if } r_{i j}<b_{j}\end{cases}
$$

一合成演算は次に示すような演算規則：

$$
r_{i j} \widetilde{\omega} b_{j}=
$$

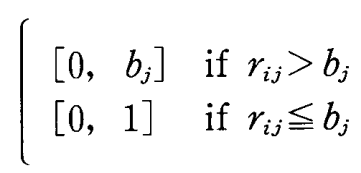

塚本の方法は以下のアルゴリズムに従う。
(1) $i \times j$ 行列 $U=\left\{u_{i j}\right\}, \widetilde{U}=\left\{\widetilde{u}_{i j}\right\}$ を求女る

$$
\left[\begin{array}{l}
U=r_{i j} \omega b_{j} \\
\widetilde{U}=r_{i j} \widetilde{\omega} b_{j}
\end{array}\right.
$$

(2) $i \times j$ 行列 $W=\left\{w_{i j}^{q}\right\}$ を求女る

$$
\begin{aligned}
& w_{i j}{ }^{q}= \\
& \left\{\begin{array}{l}
u_{i j} \text { for } \exists_{i j} \quad\left\{i \mid u_{i j} \neq \phi\right\} \\
\widetilde{u}_{i j} \text { for other } i \text { s }
\end{array}\right.
\end{aligned}
$$

ここにヨ ${ }_{i j}$ は, $\widetilde{R}$ の行に対応するインデクス で $u_{i j} \neq \phi$ を満足するものの中からただ一つだ け取り出すことを意味する.

（3）逆推論解は次のように与えられる

$$
\begin{gathered}
\hat{a}_{i}{ }^{p}=\bigcap_{j=1}^{n} w_{i j}{ }^{p}, \quad i=1, \cdots \cdot i \\
\forall p \in P,
\end{gathered}
$$

\begin{tabular}{|c|c|c|c|c|}
\hline & 用醏(1) 0.576 & 用語(2) 0.712 & 用語(3) 0.414 \\
\hline 形 & 0.061 & {$[0.061]$} & {$[0.061]$} & {$[0.061]$} \\
\hline 热 & 0.899 & {$[0.576]$} & {$[0.712]$} & {$[0.414]$} \\
\hline (1) & 0.039 & {$[0.039]$} & {$[0.039]$} & {$[0.039]$} \\
\hline 形 & 0.016 & {$[0,016]$} & {$[0.016]$} & {$[0.016]$} \\
\hline 寍 & 0.996 & {$[0.576]$} & {$[0.712]$} & {$[0.414]$} \\
\hline (2) & 0.084 & {$[0.084]$} & {$[0.084]$} & {$[0.084]$} \\
\hline 形 & 0.001 & {$[0.001]$} & {$[0.001]$} & {$[0.001]$} \\
\hline 怎 & 0.320 & {$[0.032]$} & {$[0.032]$} & {$[0.032]$} \\
\hline (3) & 0.839 & {$[0.576]$} & {$[0.712]$} & {$[0.414]$} \\
\hline 形 & 0.792 & {$[0.576]$} & {$[0.712]$} & {$[0.414]$} \\
\hline 慜 & 0.374 & {$[0.374]$} & {$[0.374]$} & {$[0.374]$} \\
\hline (1) & 0.001 & {$[0.000]$} & {$[0.000]$} & {$[0.000]$} \\
\hline
\end{tabular}

但し，Pはつぎのインデックス集合である.

$$
P=\left\{p \mid \forall_{i}, \quad\left(\bigcap_{j} w_{i j}^{p} \neq \phi\right)\right\}
$$

このアルゴリズムに従って 40 サンプル車につ いて行列 $W$ を求めた。 その一例を表 3.4 に示す (部分)。筆者らは解の上限值の 1 を少し変更し,

表3.3 同定後の $\widetilde{R}$ (部分)

\begin{tabular}{|r|r|}
\hline 用語(6) 0.459 & 用語(7) 0.630 \\
\hline$[0.061]$ & {$[0.061]$} \\
\hline$[0.459]$ & {$[0.630]$} \\
\hline$[0.039]$ & {$[0.039]$} \\
\hline$[0.016]$ & {$[0.016]$} \\
\hline$[0.459]$ & {$[0.630]$} \\
\hline$[0.084]$ & {$[0.084]$} \\
\hline$[0.001]$ & {$[0.001]$} \\
\hline$[0.032]$ & {$[0.032]$} \\
\hline$[0.459]$ & {$[0.630]$} \\
\hline$[0.459]$ & {$[0.630]$} \\
\hline$[0.374]$ & {$[0.374]$} \\
\hline$[0.000]$ & {$[0.000]$} \\
\hline
\end{tabular}

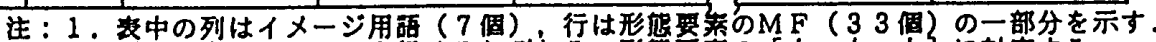

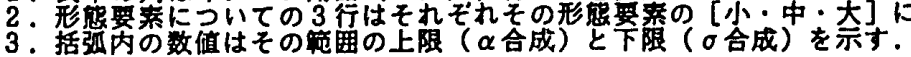


表3.4 求めた行列 $W$ (部分)

\begin{tabular}{|c|c|c|c|c|c|c|}
\hline & 用的(1) 0.576 & 用部(2) 0.712 & 用神(3) 0.414 & 用証(6) 0.459 & 用踣(7) 0.630 \\
\hline 形 & 小 & {$[0.000,1.000]$} & {$[0.000,1.000]$} & {$[0.000,1.000]$} & {$[0.000,1.000]$} & {$[0.000,1.000]$} \\
\hline 织 & 中 & {$[0.576,1.000]$} & {$[0.712,1.000]$} & {$[0.414,1.000]$} & {$[0.459,1.000]$} & {$[0.630,1.000]$} \\
\hline (1) & 大 & {$[0.000,1.000]$} & {$[0.000,1.000]$} & {$[0.000,1.000]$} & {$[0.000,1.000]$} & {$[0.000,1.000]$} \\
\hline 形 & 小 & {$[0.000,1.000]$} & {$[0.000,1.000]$} & {$[0.000,1.000]$} & {$[0.000,1.000]$} & {$[0.000,1.000]$} \\
\hline 留 & 中 & {$[0.576,1.000]$} & {$[0.712,1.000]$} & {$[0.414,1.000]$} & {$[0.459,1.000]$} & {$[0.630,1.000]$} \\
\hline (2) & 大 & {$[0.000,1.000]$} & {$[0.000,1.000]$} & {$[0.000,1.000]$} & {$[0.000,1.000]$} & {$[0.000,1.000]$} \\
\hline 形 & 小 & {$[0.000,1.000]$} & {$[0.000,1.000]$} & {$[0.000,1.000]$} & {$[0.000,1.000]$} & {$[0.000,1.000]$} \\
\hline 笖 & 中 & {$[0.000,1.000]$} & {$[0.000,1.000]$} & {$[0.000,1.000]$} & {$[0.000,1.000]$} & {$[0.000,1.000]$} \\
\hline (3) & 大 & {$[0.576,1.000]$} & {$[0.712,1.000]$} & {$[0.414,1.000]$} & $\{0.459,1.000]$ & {$[0.630,1.000]$} \\
\hline 形 & 小 & {$[0.576,1.000]$} & {$[0.712,1.000]$} & {$[0.414,1.000]$} & $\{[0.459,1.000]\}$ & {$[0.630,1.000]$} \\
\hline 態 & 中 & {$[0.000,1.000]$} & {$[0.000,1.000]$} & {$[0.000,1.000]$} & {$[0.000,1.000]$} & {$[0.000,1.000]$} \\
\hline (11) & 大 & {$[0.000, i .000]$} & {$[0.000,1.000]$} & $[0.000,1.000]\}$ & {$[0.000,1.000]$} & {$[0.000,1.000]$} \\
\hline
\end{tabular}

表3.5 変吏後の行列 $W$ (産分)

\begin{tabular}{|c|c|c|c|c|c|c|}
\hline & & 用酷(1) 0.576 & 用硬(2) 0.712 & 用西(3) 0.414 & 用酒(8) 0.459 & 用酒(7) 0.630 \\
\hline 形 & 小 & {$[0.000,0.061]$} & {$[0.000,0.061]$} & {$[0.000,0.061]$} & {$[0.000,0.061]$} & {$[0.000,0.061]$} \\
\hline 聋 & 中 & {$[0.576,0.899]$} & {$[0.712,0.899]$} & {$[0.414,0.899]$} & {$[0.459,0.999]$} & {$[0.630,0.899]$} \\
\hline (1) & 大 & {$[0.000,0.039]$} & {$[0.000,0.038]$} & {$[0.000,0.039]$} & {$[0.000,0.039]$} & {$[0.000,0.039]$} \\
\hline 形 & 小 & {$[0.000,0.016]$} & {$[0.000,0.016]$} & {$[0.000,0.016]$} & {$[0.000 .0 .016]$} & {$[0.000,0.016]$} \\
\hline 能 & 中 & {$[0.576,0.896]$} & {$[0.712,0.996]$} & {$[0.414,0.996]$} & {$[0.459,0.996]$} & {$[0.630,0.896]$} \\
\hline (2) & 大 & {$[0.000,0.084]$} & {$[0.000,0.084]$} & {$[0.000,0.084]$} & {$[0.000,0.084]$} & {$[0.000,0.084]$} \\
\hline 形 & 小 & {$[0.000,0.001]$} & {$[0.000,0.001]$} & {$[0.000,0.001]$} & {$[0.000,0.001]$} & {$[0.000,0.001]$} \\
\hline 慜 & 中 & {$[0.000,0.320]$} & {$[0.000,0.320]$} & {$[0.000,0.320]$} & {$[0.000,0.320]$} & {$[0.000,0.320]$} \\
\hline (3) & 大 & {$[0.576,0.839]$} & {$[0.712,0.839]$} & {$[0.414,0.839]$} & {$[0.459,0.839]$} & {$[0.630,0.839]$} \\
\hline 形 & 小 & {$[0.576,0.782]$} & {$[0.712,0.792]$} & {$[0.414,0.792]$} & {$[0.459,0.782]$} & {$[[0.630,0.792]$} \\
\hline 照 & 中 & {$[0.000,0.374]$} & {$[0.000,0.374]$} & {$[0.000,0.374]$} & {$[0.000,0.374]$} & {$[0.000,0.374]$} \\
\hline (11) & 大 & {$[0.000,0.001]$} & {$[0.000,0.001]$} & {$[0.000,0.001]$} & {$[0.000,0.001]$} & {$[0.000,0.001]$} \\
\hline
\end{tabular}

解の幅を㚘めて実際のデザイン作業をやりやすく することを検討しなが，その結果，解の幅は妥当 と思われた。変更後の合成演算を以下に示し，そ れ老用いて演算した行列 $W$ の結果の一例を表 3.5 (部分)に示古。求㚾れた行列 $W$ を用いて, 多数の解が求められる。

$$
\begin{aligned}
& r_{i j} \omega b_{j}(\omega-\text { 合成演算 })=
\end{aligned}
$$

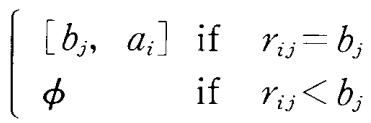

$$
\begin{aligned}
& r_{i j} \widetilde{\omega} b_{j}(\widetilde{\omega}-\text { 合成演算 })= \\
& \left(\begin{array}{ccc}
{\left[\begin{array}{ll}
0, & b_{j}
\end{array}\right]} & \text { if } & r_{i j}>b_{j} \\
{\left[\begin{array}{ll}
0, & 1
\end{array}\right]} & \text { if } & r_{i j} \leqq b_{j}
\end{array}\right.
\end{aligned}
$$

\section{4. 推論解の性質}

哿節で得られた解は，1倜ではなく多数存在す る場合が多い。これらの解に対して積集合と利集 合の方法で[必然解] [ [可能解]をそれぞれ求めた。 すなわち，どの解の範四に対しても共通な解とし て[必然解], 全部の解で得られた最小值と最大值 を含む解として[可能解]を定義した。これに従つ て, 各車の逆推論解を [必然解 $]$ と[可能解]に分解 した。 


\section{4. ニューラルネットによる学習}

\section{1. 考え方}

ファジィ関係方程式の逆部算(逆推論)を使って 幅のある逆推論解が得られるが，デザイン閌題の 一般の性筫として本論の芬命もファジィ阅係式が サンブルごとにかなり相橾する。つまり関係の满 造があいまいかの不盗である。しかも变数湍の独 性も保部さされていないという䦌题があるために， 逆推論結果は信頼性に久忛る。このような埸命に おいては，構造を䦌題にしないで複篗な関倸をモ デル化するニューラルネットワークモデル（以降 $\mathrm{NN}$ と略寸)でサンプルの逆推渝在まとめて推論 するのが份効と照われるので，逆推論の過程に NNを等入した。

\subsection{NNの構造及び学習パーダン}

各解のト下限を二つのパーセブトロン型の

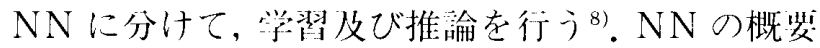
は以下の通り（洞 4.1）：

\section{人力数：7橭(イメージ肘衙対忍)}

出力数：33 做(形態裂絭のメンバーシップ值刘 忍）

中間層：2 屏(ユニット数：25 と 17)

学桨パターン：40 湖(40 サンプル本の逆推論 解)

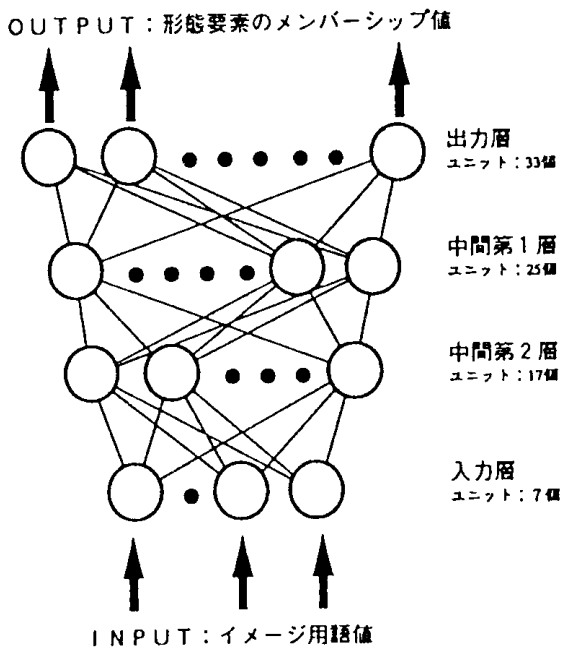

図4.1 NN の概略図

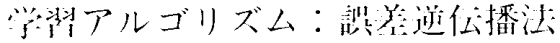

NNの数：3湖(それぞれ必然解のト限, 叮能解 のト限と屾解の上陵に対灾）

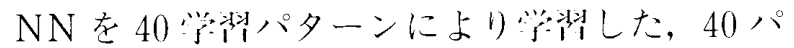
ターンの総鿁养はそれぞ扎 $0.53,0.51,0.17$ まで 落とした。

\section{3. 推論データの解釈法について}

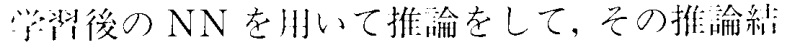
果をデザイナーに提小寸る際，デザイナーの必装 に忍じて，文献 9)により，以下の3 㮔の提小法が ある：

(1)、泪レベル提尔注

(2) 碓储度の数值レベル提小法

(3)北ファジィ化の数值レベル提小法

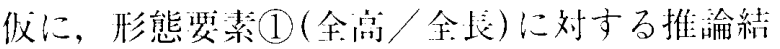
果が, [全宫が低い]のメンバーシップ值は 0.2 , [金宫が问い]のメンバーシップ做は 0.5 , [どちら でもない]のメンバーシップ佰は 0.8 とする(汹 4.2).

方法(1)の言涪レベル法では, 3 湖のファジイ集 合に対するそれぞれの言語レベルで表す。すなわ ち，0.8を[形容詞なし]として，0.2を[はとん ど・・ないとして，0.5を[すこしとして、䛇化 寸る。従って、記結果は

「宲くも低くもないが，少し富めにしなさい， 低くしてもほとんど意味ありません」

J゙法(2)の確信度数值法では，3 個のファジイ集 合への帛属度 $(0.2,0.5,0.80$ ようなメンバーシッ

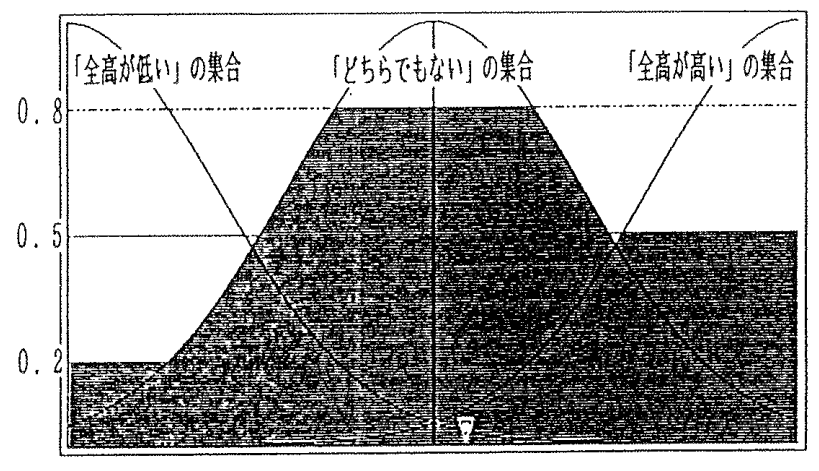

$\rightarrow$ 車高計測值

図4.2推論結果の例 
プ）確信度として表す,

「平均的な車を基準としたとき $[$ 低い]に対して 0.2 ，[高い]に対して 0.5 ，［どちらでもない]に対 して 0.8 の確信度」

方法 (3)の非ファジィ化数值法では, 推論メンバ ーシップ值を前述の非ファジィ化方法を用いて， 非ファジィ化した後の数值を提示する.

[全高対全長の比は約 0.31 (全高はほぼ全長の $1 / 3$ 弱位にしなさい)

どの方法でもデザイナーに対して有用と思われる。

\section{5. 構築されたモデルの有効性検証}

\section{1. 学習に用いたデータによる検証}

有効性の検証に当たっては，まず既知デー夕で 検証するため学習に用いた 40 サンプル車の中か らランダムに 4 車 (日本車 2 車, 外車 2 車)を選ん で，試推論の対象とした，前章で述べた学習後の NN でメンバーシップ值を推論し，非ファジィ化 後の推論值と実車の值の比較を表 5.1 に示す。各
実車は解の一つであることに違いないからその值 は推論幅に入るはずであるが必ずしも推論幅に入 らない。しかし全体としてほぼ妥当な推論ができ たと思われる。

\section{2 仮データによる検証一光の 1}

次に，あるコンセプトがイメージ用語値の組み 合わせとして立案されたとき，それを入力デー夕 として推論し，その結果から検証を行う。入力デ ータはランダムに何組かを選び，その中から例え ば先進的とオーソドックスの雨方ともに強く求め られるというような矛盾がないことが確認された 組の中から一つを選び出して試推論をした。入力 データとその結果を表 5.2 に示す.

\section{3. 仮データによる検証一光の 2}

上述の仮データ以外に, あるイメージ用語が $[$ 子 つう 強い]に変化する際, 対応する形態要素がど のような変化を示すかを調べることで検証を行う.

表5.1 推論解と実車の值との比較

\begin{tabular}{|c|c|c|c|c|c|}
\hline \multirow{3}{*}{$\begin{array}{l}\text { 形䖵 } \\
\text { 要素 }\end{array}$} & \multirow{3}{*}{ 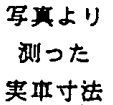 } & \multicolumn{2}{|r|}{ 推 } & \multicolumn{2}{|c|}{ 间 解 } \\
\hline & & i & 解 & 可 & 能 \\
\hline & & [下 & 上 限] & [ $\left[\begin{array}{ll}\text { 下 } & \text { 限 }\end{array}\right.$ & ，上 限] \\
\hline (1) & 0.318 & {$[0.303$} & $.0 .317]$ & {$[0.303$} & . 0.318$]$ \\
\hline (2) & 0.282 & {$[0.284$} & .0 .301 & {$[0.283$} & .0 .303 \\
\hline (3) & 0.094 & {$[0.061$} & $0.101]$ & {$[0.063$} & $.0 .101]$ \\
\hline (4) & 29.688 & {$[28.200$} & $.30 .020]$ & {$[27.956$} & $.30 .052]$ \\
\hline (5) & 24.336 & {$[20.219$} & . 26.496] & {$[19.395$} & . 26.496] \\
\hline (6) & 0.040 & {$[0.043$} & $.0 .071]$ & {$[0.041$} & $0.072]$ \\
\hline (7) & 0.309 & {$[0.233$} & $0.309]$ & {$[0.223$} & $0.309]$ \\
\hline (8) & 6.000 & {$[4.510$} & $.5 .784]$ & {$[4.389$} & $5.860]$ \\
\hline (9) & 0.649 & {$[0.623$} & $0.644]$ & {$[0.620$} & $0.644]$ \\
\hline (10) & 1.799 & {$[1.218$} & $1.753]$ & {$[1.178$} & $1.793]$ \\
\hline (11) & 8.757 & [8.721 & $10.517]$ & {$[8.534$} & $10.661]$ \\
\hline
\end{tabular}

\begin{tabular}{|c|c|c|c|c|c|}
\hline \multirow{3}{*}{$\begin{array}{l}\text { 形態 } \\
\text { 要索 }\end{array}$} & \multirow{3}{*}{$\begin{array}{c}\text { 军真より } \\
\text { 湘った } \\
\text { 实中寸法 }\end{array}$} & \multicolumn{4}{|c|}{ 推 諭 } \\
\hline & & \& & 解 & 可 & 解 \\
\hline & & [下 & ，上 限] & {$\left[\begin{array}{ll}{[\text { 下 }} & \text { 限 } \\
\end{array}\right.$} & 上 限] \\
\hline (1) & 0.320 & {$[0.313$} & $. \quad 0.321]$ & {$[0.310$} & $0.322]$ \\
\hline (2) & 0.275 & {$[0.255$} & $.0 .290]$ & {$[0.259$} & 0.294 \\
\hline (3) & 0.135 & {$[0.110$} & , 0.135$]$ & {$[0.106$} & $0.136]$ \\
\hline (4) & 28.615 & {$[30.041$} & , 33.974] & {$[29.611$} & $34.016]$ \\
\hline (5) & 33.477 & {$[24.900$} & $.29 .040]$ & {$[24.694$} & $29.605]$ \\
\hline (6) & 0.078 & {$[0.080$} & $.0 .093]$ & {$[0.075$} & 0.098 \\
\hline (7) & 0.255 & {$[0.222$} & $0.310]$ & {$[0.213$} & $0.307]$ \\
\hline (8) & 5.000 & {$[4.131$} & $5.615]$ & {$[3.908$} & $5.722]$ \\
\hline (9) & 0.630 & 0.576 & $, 0.603]$ & {$[0.576$} & $0.608]$ \\
\hline (10) & 1.180 & {$[1.210$} & $1.868]$ & {$[1.157$} & $1.934]$ \\
\hline (1) & 10.383 & {$[9.151$} & $.10 .912]$ & {$[9.028$} & $11.120]$ \\
\hline
\end{tabular}

\begin{tabular}{|c|c|c|c|c|c|}
\hline \multirow{3}{*}{ 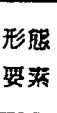 } & \multirow{3}{*}{$\begin{array}{c}\text { 写真より } \\
\text { 测った } \\
\text { 实車寸法 }\end{array}$} & \multicolumn{2}{|r|}{ 推 } & \multicolumn{2}{|c|}{ 解 } \\
\hline & & i & 解 & 可 & 能 \\
\hline & & [下 限 & 上 限] & [下 $\quad$ 限 & , 上 限] \\
\hline (1) & 0.317 & {$[0.308$} & $0.316]$ & {$[0.306$} & $.0 .321]$ \\
\hline (2) & 0.269 & {$[0.269$} & $\therefore \quad 0.290]$ & {$[0.269$} & $.0 .303]$ \\
\hline (3) & 0.127 & {$[0.104$} & $.0 .134]$ & {$[0.088$} & $.0 .137]$ \\
\hline (4) & 31.124 & {$[29.173$} & . 30.836$]$ & {$[28.523$} & . 31.759] \\
\hline (5) & 27.109 & {$[20.720$} & $.26 .589]$ & {$[17.234$} & , 27.333] \\
\hline (6) & 0.065 & {$[0.055$} & $.0 .080]$ & {$[0.049$} & $0.094]$ \\
\hline (7) & 0.255 & {$[0.211$} & $0.241]$ & {$[0.188$} & $.0 .256]$ \\
\hline (8) & 6.000 & {$[4.371$} & $\begin{array}{l}5.851] \\
\end{array}$ & {$[3.680$} & $.6 .438]$ \\
\hline (9) & 0.643 & {$[0.621$} & $0.644]$ & {$[0.606$} & $, 0.647]$ \\
\hline (10) & 1.301 & {$[1.097$} & $1.636]$ & {$[0.828$} & $1.802]$ \\
\hline (11) & 11.710 & {$[10.613$} & $11.743]$ & {$[9.960$} & $12.719]$ \\
\hline
\end{tabular}

\begin{tabular}{|c|c|c|c|c|c|}
\hline \multirow{3}{*}{ 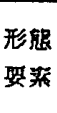 } & \multirow{3}{*}{$\begin{array}{c}\text { 写真より } \\
\text { 测った } \\
\text { 实州寸法 }\end{array}$} & \multicolumn{3}{|c|}{ 推 媩 } & 解 \\
\hline & & 必 & 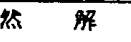 & 可 & 解 \\
\hline & & {$\left[\begin{array}{ll}\text { 下 } & \text { 限 }\end{array}\right.$} & ，上 限了 & [下 & ，上 限] \\
\hline (1) & 0.282 & {$[0.282$} & $.0 .298]$ & {$[0.281$} & $.0 .308]$ \\
\hline (2) & 0.291 & {$[0.289$} & $.0 .308]$ & {$[0.286$} & $0.319]$ \\
\hline (3) & 0.071 & {$[0.057$} & $.0 .091]$ & {$[0.058$} & $0.116]$ \\
\hline (4) & 24.052 & {$[24.151$} & $26.875]$ & {$[24.154$} & 28.878 \\
\hline (5) & 18.147 & {$[16.074$} & . 19.788] & {$[13.033$} & 23.969] \\
\hline (6) & 0.056 & {$[0.053$} & $0.078]$ & {$[0.045$} & $0.092]$ \\
\hline (2) & 0.254 & {$[0.208$} & $0.241]$ & {$[0.179$} & $0.260]$ \\
\hline (8) & 2.000 & {$[1.459$} & . 3.499] & [ 1.280 & . 4.966] \\
\hline (9) & 0.648 & {$[0.618$} & $, \quad 0.645]$ & {$[0.602$} & . 0.645$]$ \\
\hline (10) & 0.671 & {$[0.669$} & $, 1.110]$ & {$[0.441$} & $.1 .460]$ \\
\hline (1) & 7.943 & {$[8.104$} & $9.589]$ & {$[7.198$} & $.10 .415]$ \\
\hline
\end{tabular}


ここでは，デザイナーの知識と比較しやすくする ために，イメージ用語は[シャープな]として，対 応する形態要素は[車高・ウエストラインの傾斜 度・フロントの傾斜度］をとり上げた，[シャープ な]の程度を増分 0.05 で, 0.5 から 1.0 までの 11 個のデータとした。その推論結果の必然解を図 5.1 に示す，困中の 2 本線はそれぞれ必然解の上 限と下限を示す。

すなわち，[シャープさ］を強くしたいときには， 最も重要なのは [フロントを大きく傾斜する]こと， 同時に[ウエストラインもすこし傾斜する]が解で

表5.2 未知仮データの推論結果

\begin{tabular}{|c|c|c|}
\hline \multirow{2}{*}{ 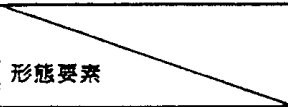 } & \multicolumn{2}{|r|}{ 䑫 } \\
\hline & $\begin{array}{ccc}\text { 必 } & \text { 然 } \\
\text { [下 }\end{array}$ & {$\left[\begin{array}{ccc}\text { 可 } & \text { 能 } \\
{[\text { [ 解 }}\end{array}\right.$} \\
\hline (1)全高/全取比 & {$[0.301,0.314]$} & \begin{tabular}{|l|}
{$[0.284$} \\
\end{tabular} \\
\hline (2)フロント長/全长比 & {$[0.286$} & {$[0.287$} \\
\hline (3リヤ旦／全長比 & {$[0.107$} & {$[0.078$} \\
\hline 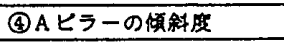 & {$[28.283$} & {$[29.281$} \\
\hline (5Cヒララーの慎斜度 & {$[17.781,26.560]$} & {$[17.757,38.411]$} \\
\hline (6)バンパーの英出度 & {$\left[\begin{array}{lll}0.037,0.073] \\
0\end{array}\right.$} & {$[0.027$} \\
\hline (7)ハンパーの示さ & {$[0.207$} & {$[0.141$} \\
\hline (8)丸み & {$[3.874$} & $\begin{array}{l}3.525 \\
\end{array}$ \\
\hline (9ウエストライン高/全离 & {$[0.614$} & {$[0.614$} \\
\hline (9)エストラインの佰斜珄 & {$[1.161$} & {$[1.185$} \\
\hline (1)フロントの偭斜展 & {$[10.553,12.306]$} & {$[9.588,10.866]$} \\
\hline 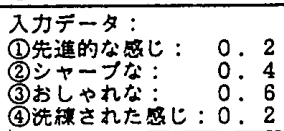 & 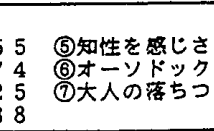 & 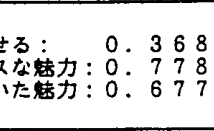 \\
\hline
\end{tabular}

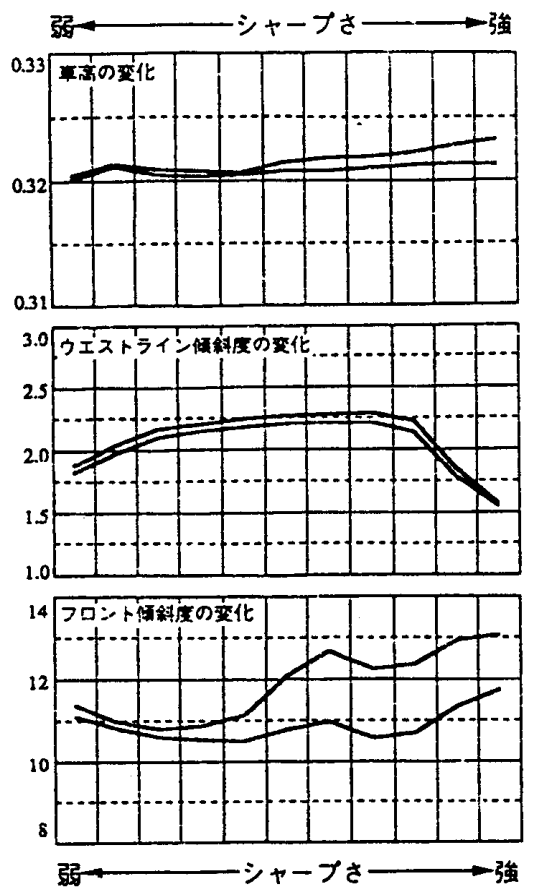

图5.1 仮データによる検証グラフ (困中の2本線は推論必然解の上・下限を示す)
あるが，特に強く[シャープさ]を求める，すなわ ち龱の右方においては，フロントを大きく傾斜す るにつれて，車のデザインの実際の問題として， ウエストラインの傾斜の余地がなくなる (先端の スペースがなくなる)ので，その对応方法として， [ウエストラインの傾斜を戻す］とともに[僅かだ が, 全高を高くする]が解であることが図からも読 み取れる。すなおち，本モデルは単に単独の形態 要素に対して推論するのでなく, 全形態要素を考 虑して上述のような形態要素間における相互関係 も学習パターンから学習して総合的に推論してい ることが分かった。これにより，本モデルの有効 性が示された。

\section{6. 結論}

本研究は，デザインの支援のためにニューラル ネットで推論する方法を利用してファジィ逆推論 を行うモデルを提案した。このようなモデルを[ニ ューラルネットで統合するファジィ逆推論モデ ル]と名付け, 自動車デザインのために外観イメー ジからスタイルの造形解を求める過程についてシ ステムを構築した，システムを考察した結果，モ デルの特徴は以下の 2 点にある：

(1)ファジィメンバーシップ関数を用いて,モデ ルを一層人の認知に近いものにした（2).ニュー ラルネットを用い，ファジィ関係式があいまいな 場合においても，逆推論できるようにした，構築 されたシステムをデザインへ応用する際，その有 効性が数値例によって示された。

\section{参 考 文 献}

1)森 典彦, 杉山 和雄, 他：”工業デザインにおけ る外観イメージ用語と形態要素の関係に関する 研究”, 千葉大学工学部工業意匠学科工業意匠研 究室研究報告書, p.2-p.6, 1986

2) 本多 中二, 大里 有生 : "ファジィ工学入門”, 海 文堂, p.62-p.65, 1989

3)田中一男, : ”応用をめざす人のためのファジィ 理論入門”，ラッセル社，P.29-P.35，1991 4) 同2) p.48-p.54 


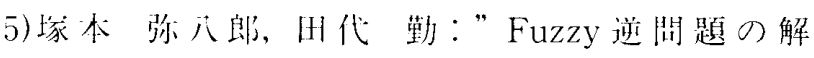
法”, 㖕测问動制御黄会論文集, Vol.15, No.1, p. $21-$ p. $25, \quad 1979$

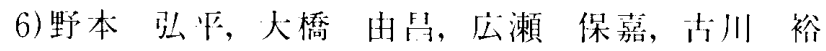
之：”逐次型ファジィ後向き推論を䏘いた日標類 别”, 電子情報通倍学全論文誌, Vol.J74-D-I,No. 2, 1991

7）䉓短学会：”あいまいとファジィ”，オーム社, p.155 - p.181, 1991

8)本研究に徆いた尌算ソフトは，ブレンズ祄の[網力 太]で，構築及び計算できるサイズの制限により， 冬解のト下限を二つの NNに分けて兴翼及び推 論在行门。

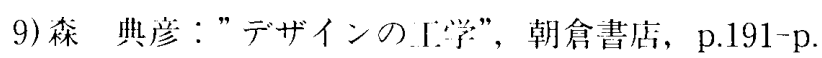
214,1991

\author{
（1992年12月12日 受 付） \\ （1993年 5月10日 撃受付）
}

[湖い合わ世先]

干260 下葉汸稻毛弥生:町1-33

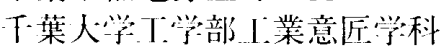
デザインシステム部画研究分野

偯 育銘

[TEL) : 043-290-3100

EAX): 043-290-3099

\section{著者紹介}

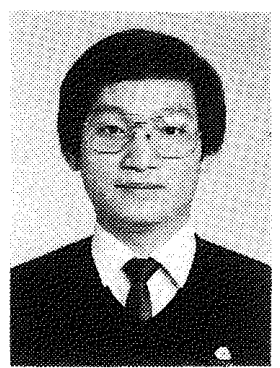

\section{張 育銘(チャンュウミン)}

千葉大学大学院然科学研究科 1982年台湾国吉成功大学，業設 㖕学科卒業。1973年退役後台湾松 卜電器 (株)に入社, 洗濯機／乾燥機 等の率品企西・デザインに従事. 1988 年上り）葉大学入留受。１990年间大 学:大学院上鄴意匠学専攻修士課程を 卒業, 兒在汇间大学博上課程に在学: ゆ、デザインに関する研究に興味を 持つ，目本ファジィ学:会，川本デザイ 学会会真.

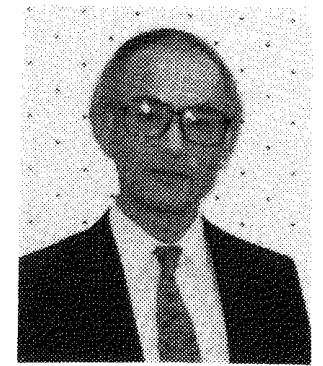

森 典彦(もりのりひこ)

下葉大学[学部

1955年 東京大学工学部忍用物理 学科卒業。同年プリンス白動車設 計部。1962年 JETRO 派遣研究員と してドイッ/ウルム造形大学. 帰国 後日座日動串造形部の後, 问社商品 開発室総合郭画部主管。1984年 下葉 大学工学部教授 (工業意匠学科)。自 動車および一般デザインの工学的方 法を研究. 著書「デザインの工学」(朝 畣書店)，「左脳デザイニング」(海文 堂, 編著) 等。日本デザイン学会, 日 本ファジィ学会, 計測自動制御学会, 任動車技術会会負。 


\section{A Design Support System For Cars Using Fuzzy Inverse Reasoning Integrated by Neural-Network Yu-Ming CHANG \\ Graduate School of Chiba University \\ 1-33, Yayoichou, Inageku, Chibashi, 260 Japan}

\section{Norihiko MORI}

Chiba University

1-33, Yayoichou, Inageku, Chibashi, 260 Japan

In order to reduce the workload of designers and to help them stimulate ideas, several support systems for car styling design have been investigated. These systems are aimed at changing the designer's thinking process into objective models and then reasoning other cases from this model.

However, many of these models have two problems; firstly, variables of the formative styling elements combine subjective scales and measurable scales, and secondly the reasoning process lacks the flexibility of that of the designer. In this paper, therefore, in order to solve these problems, the authors propose a more flexible model which improves the formative element variables, changing these variables from measurable scales to subjective scales by the use of fuzzy sets. Additionally, by the use of fuzzy inverse reasoning, broad styling solutions can be produced.

A problem of the design process is that the fuzzy relational matrix contains ambiguities, and therefore a reasoning method using a neural network was introduced into the system. The process of evolving the styling from conceptual images of cars was used as a sample study in order to demonstrate the design support system developed in this paper, and by the use of practical data, the efficiency of this model was confirmed.

Keywords : Fuzzy Inverse Reasoning, Neural Network, Subjective Scales, Styling, Cars, Design 